\title{
Reliability of Different Environmental Noise Monitoring Programs in Serbia
}

\author{
Darko MIHAJLOV*, Momir PRAŠČEVIĆ, Marko LIČANIN, Miomir RAOS
}

\begin{abstract}
Annual environmental noise monitoring is a legal requirement for local self-governments in the Republic of Serbia. However, Serbian legislation does not stipulate specific monitoring procedures, so each local self-government unit has to create its own environmental monitoring program within its jurisdiction. This paper analyzes the reliability of noise monitoring programs in local self-government units, based on short-term measurements. The reliability of applicable environmental noise monitoring programs in Serbia was examined by simulating the program imlementation to the results of noise monitoring obtained through continuous measurement over a period of one year. The above mentioned simulation showed that the monitoring programs based on short-term monthly measurements and a measurement time interval over 24 hours have the best repeatability and reliability result, especially at locations with the same daily noise profile and the occasional occurrence of unexpected short-term noise events. The results obtained in this study indicated that, either with higher or lower degrees of reliability, other programs can be used to monitor noise at measurement points near major urban roads with heavy and relatively constant vehicle flow throughout the day.
\end{abstract}

Keywords: long-term measurements; noise monitoring; road traffic noise; short-term measurements

\section{INTRODUCTION}

The quality of life in urban environments, proper functioning, and successful performance of everyday tasks depend on, among other things, the noise levels throughout the day, particularly during night time. Remaining in highnoise-level environments for prolonged periods can reduce a person's operational and cognitive abilities, negatively affect their mood, and even lead to serious health effects $[1,2]$.

Road traffic is the dominant source of noise in urban environments [3]. It is the most common noise source in all European countries and the chief cause of disturbance to human activities [4]. Despite the advances in the automobile industry resulting in the manufacture of lownoise engines, an increasing number of cars, public utility vehicles, public transport vehicles, delivery vehicles, and motorcycles within the existing transport infrastructure create an environment in which noise poses a serious problem [5]. In addition to road traffic, other environmental noise sources include intensified human communication, outdoor sports activities, construction work, and various services (shops, restaurants, and servicing stations or workshops for different purposes), which aim to meet the demands of the local communities.

In the previous decade, several analyses of the state of environmental noise were performed in Serbia [6-9] with the aim of inciting the implementation of technical and legislative measures to control the noise, as well as healthcare measures to protect the population from its harmful effects [10]. Many European and world cities are particularly focused on developing technical systems for environmental noise monitoring based on advanced technologies [11-14], as well as on developing models for environmental noise prediction centred around road traffic as the dominant source [15-19].

The data on the annual noise level at a specified fixed point in the environment is obtainable from a strategic noise map or from a year-long noise monitoring at a given point [20]. Mandatory creation of strategic noise maps in EU cities is stipulated in the Directive 2002/49/EC [21]. The existence of a strategic noise map does not exclude the necessity of noise monitoring at fixed points. Such monitoring is organized for the following reasons:
- to calibrate strategic noise maps for the same operating conditions of the noise source;

- to determine the state of noise under new, permanently altered, conditions as opposed to the previous conditions, which were included in the calculations for strategic map design (e.g. transport infrastructure, vehicle flow and structure, number and acoustic properties of noise sources, etc. which changed in the meantime);

- to determine the state of noise under new, temporarily altered conditions due to a temporarily altered structure of noise sources in the immediate surroundings construction work, sports or cultural events, etc.;

- to control the noise levels in areas that are particularly sensitive to noise (rest and recreation areas such as parks and outdoor sporting grounds or healthcare and educational institutions), especially if they are susceptible to excessive noise levels.

In all the aforementioned cases, noise is monitored according to a predefined program, which depends on the purpose of the data obtained through the monitoring, in accordance with the ISO 1996-2:2017 standard [22].

By the end of 2020, Niš was the only Serbian city to have its strategic noise map created. The data on the state of noise levels in other cities can be obtained from their annual noise monitoring [23], which is a legal requirement [24] for every local self-government. In addition to legal transactions and procedures, implementation of noise monitoring under a local self-government jurisdiction also involves the creation of a monitoring program. A program for noise monitoring at fixed measurement points contains data on the number and layout of measurement points, the measurement time interval, measured quantities, and noise measurement schedule.

The aim of annual noise monitoring at predefined fixed measurement points is to determine the annual values of $L_{\text {day }}, L_{\text {evening, }} L_{\text {night }}$ and $L_{\text {den }}$ noise indicators in order to check for compatibility with noise levels limits in the acoustic zone of a given location, to asses the health impact on the people who reside within the location, and to potentially develop noise reduction measures [25, 26].

The $L_{\text {den }}$ total annual noise indicator, which describes noise interference for a year-long period, is defined as follows [21]: 


$$
L_{\mathrm{den}}=10 \log \left[\frac{1}{24}\left(\begin{array}{c}
12 \cdot 10 \frac{L_{\mathrm{day}}}{10}+ \\
+4 \cdot 10 \frac{L_{\mathrm{evening}}+5}{10}+ \\
+8 \cdot 10 \frac{L_{\mathrm{night}}+10}{10}
\end{array}\right)\right], \mathrm{dB}
$$

where: $L_{\text {day }}$ - A-weighted long-term average sound level determined over all daytime periods of a year; $L_{\text {evening }}-\mathrm{A}$ weighted long-term average sound level determined over all evening periods of a year; $L_{\text {night }}$ - A-weighted long-term average sound level determined over all night time periods of a year.

The A-weighted long-term average sound levels for specific reference periods of a year (1) are determined using the following expression:

$$
L_{\text {day/evening/night }}=10 \log \left[\frac{1}{\mathrm{~N}} \sum_{\mathrm{i}=1}^{\mathrm{N}} 10 \frac{L_{\text {day/evening/night }, i}}{10}\right], \mathrm{dB}
$$

where: $i$ - ordinal number of a day in a year $(i=1 \div 365)$; $\mathrm{N}$ - total number of days in a year (365).

The term year in the expressions above refers to a relevant year in terms of noise emissions and an average year in terms of weather conditions.

\section{CHARACTERISTICS OF NOISE MONITORING PROGRAMS RELYING ON SHORT-TERM MEASUREMENTS}

Annual noise monitoring at a fixed measurement point can be conducted through programs comprising different monitoring strategies.

Completely reliable annual noise indicator values (absolutely precise and accurate) can only be obtained from permanent noise monitoring - long-term continuous measurement with a measurement time interval of one calendar year, encompassing all operational changes in different noise sources and all the weather changes throughout the year [27]. Such a monitoring strategy requires specialized measuring equipment - automated noise monitoring systems and substantial logistical support.

On the other hand, the results that provide a high degree of reliability can also be obtained through calculations based on the results obtained from semipermanent noise monitoring (long-term continuous monitoring with a measurement time interval of less than one calendar year) [28], or based on noise monitoring that utilizes a series of short-term measurements with common measurement time intervals of 15 minutes or 24 hours, following a specified schedule over the course of a year.

The use of a variety of monitoring programs is a result of several factors, depending on the particular characteristics of different cities, such as terrain configuration, road characteristics, traffic structure and volume, the number and position of noise-sensitive structures, the contribution of specific noise sources to the general state of noise level, etc. Ultimately, the analysis of results from previous years and the extensive practical experience with environmental noise monitoring are crucial factors when selecting a monitoring program strategy and creating a schedule.

The reliability of the results obtained from a series of short-term noise measurements according to a specified yearly schedule, and thus the reliability of the given program, can be checked using a simulation of how the specified program is applied to the noise monitoring results obtained from continuous permanent annual monitoring. Since such results are considered completely reliable, they can be used to test the reliability of different environmental noise monitoring programs that are based on a series of short-term measurements.

\begin{tabular}{|c|c|c|c|c|c|}
\hline \multirow{2}{*}{$\begin{array}{c}\text { Program: } \\
\text { Designation, } p\end{array}$} & LESKOVAC & NIŠ & BEOGRAD & NOVI SAD & SOMBOR \\
\hline & 1 & 2 & 3 & 4 & 5 \\
\hline $\begin{array}{l}\text { Measurement time } \\
\text { interval, } t\end{array}$ & $15 \mathrm{~min}$ & $15 \mathrm{~min}$ & $24 \mathrm{~h}$ & $24 \mathrm{~h}$ & $24 \mathrm{~h}$ \\
\hline $\begin{array}{l}\text { Measured quantities } \\
\text { / dB }\end{array}$ & $L_{\text {Aeq }, t}$ & $L_{\mathrm{Aeq}, t}$ & $L_{\text {day }}, L_{\text {evening }}, L_{\text {night }}$ & $L_{\text {day }}, L_{\text {evening }}, L_{\text {night }}$ & $L_{\text {day }}, L_{\text {evening }}, L_{\text {night }}$ \\
\hline $\begin{array}{l}\text { Number of measurement } \\
\text { periods in } 24 \mathrm{~h}, \mathrm{~m}\end{array}$ & 5 & 6 & - & - & - \\
\hline Measurement schedule & $\begin{array}{l}12 \text { months, one } 15-\text { min } \\
\text { measurement in each } \\
\text { measurement period, } 1 \\
\text { day per month }{ }^{1)}\end{array}$ & $\begin{array}{c}12 \text { months, one } 15 \text {-min } \\
\text { measurement in each } \\
\text { measurement period, } 6 \\
\text { days per month }^{2)}\end{array}$ & $\begin{array}{c}1 \text { day in the spring } \\
\text { and } 1 \text { day in the } \\
\text { autumn }\end{array}$ & 12 months & $\begin{array}{c}4 \text { months, three cycles } \\
\text { for different } \\
\text { measurement points }{ }^{3)} \text { : } \\
\text { Jun-Sept, Oct-Jan, } \\
\text { Feb-May }\end{array}$ \\
\hline $\begin{array}{c}\text { No. of measurements per } \\
\text { measur. point }\end{array}$ & $\begin{array}{l}5 \text { per month, } 60 \\
\text { times per year }\end{array}$ & $\begin{array}{l}6 \text { per month, } 72 \\
\text { times per year }\end{array}$ & $\begin{array}{c}1 \text { per month, } 2 \text { times } \\
\text { per year }\end{array}$ & $\begin{array}{l}1 \text { per month, } 12 \\
\text { times per year }\end{array}$ & $\begin{array}{c}1 \text { per month, } 4 \text { times } \\
\text { per year }\end{array}$ \\
\hline $\begin{array}{c}\text { Method of calculating } \\
\text { annual noise indicator } \\
\text { values }\end{array}$ & $\begin{array}{l}\text { Mean value of } 12 \text { daily } \\
\text { noise indicators } \\
\text { obtained from monthly } \\
\text { measurement results }\end{array}$ & $\begin{array}{c}\text { Mean value of three } \\
\text { daily noise indicators } \\
\text { obtained from } \\
\text { quarterly measurement } \\
\text { results } \\
\end{array}$ & $\begin{array}{l}\text { Mean value of two } \\
\text { daily noise indicators }\end{array}$ & $\begin{array}{l}\text { Mean value of } 12 \\
\text { daily noise indicators }\end{array}$ & $\begin{array}{l}\text { Mean value of four } \\
\text { daily noise indicators }\end{array}$ \\
\hline $\begin{array}{l}{ }^{1)} \text { Leskovac: Flexible choi } \\
\text { p.m.; } 10 \text { p.m. - } 1 \text { a.m.; } 1 \text { a. } \\
\text { 2) Niš: One } 15 \text {-minute mea } \\
\text { - } 2 \text { a.m.; } 2 \text { a.m. - } 6 \text { a.m.); } \\
\text { the measurement periods } \\
\text { the } 15 \text {-minute measureme } \\
\text { 3) Sombor: Continuous } 24\end{array}$ & $\begin{array}{l}\text { ne of times is allowed } f \\
\text { m. - } 5 \text { a.m.), which mea } \\
\text { urement per month in } \\
\text { y one hour every montl } \\
\text { t within one hour in ea }\end{array}$ & $\begin{array}{l}\text { the } 15 \text {-minute measure } \\
\text { that measurement time } \\
\text { ary measurement period } \\
\text { over the following four } \\
\text { The monitoring progran } \\
\text { measurement period, w }\end{array}$ & $\begin{array}{l}\text { ent within a one-day } \\
\text { nay overlap over mul } \\
\text { a.m. - } 10 \text { a.m.; } 10 \text { a.n } \\
\text { honths with a circular } \\
\text { llows the flexibility o } \\
\text { ch results in one meas }\end{array}$ & $\begin{array}{l}\text { d (9 a.m. - } 1 \text { p.m.; } 2 \\
\text { months. } \\
2 \text { p.m.; } 2 \text { p.m. }-6 \text { p.m } \\
\text { aslational) shift of th } \\
\text { oosing one of the for } \\
\text { ment per each of the }\end{array}$ & $\begin{array}{l}-5 \text { p.m.; } 6 \text { p.m. - } 10 \\
\text { m. - } 10 \text { p.m.; } 10 \text { p.m. } \\
\text { surement start during } \\
\text { sible times of day for } \\
\text { ars over four months. }\end{array}$ \\
\hline
\end{tabular}

Table 1 Characteristics of environmental noise monitoring programs in selected Serbian cities in 2020 
Noise monitoring in Serbian cities is conducted through a series of short-term measurements of specific noise parameters during one calendar year and according to the predefined programs. Tab. 1 shows the characteristics of five environmental noise monitoring programs in selected Serbian cities. In each program, noise monitoring is scheduled for weekdays only.

The measurement points in the analyzed programs for annual noise monitoring are prevalently located at 'noisy' locations, where high values of annual noise indicator values are assumed, including potential values in excess of the allowed limits. Road traffic is the dominant noise source at all the examined locations. Accordingly, the results of annual monitoring at measurement points exposed to noise with the same origin and character were used to test the reliability of specific programs, with road traffic being the dominant noise source throughout.

\section{RESULTS OF LONG-TERM CONTINUOUS NOISE MONITORING IN THE CITY OF NIŠ}

In addition to the monitoring based on a series of shortterm noise measurements, long-term continuous monitoring of environmental noise has also been conducted in Niš since 2014. Tab. 2 shows the results of long-term permanent noise monitoring during one calendar year conducted at two measurement points in Niš by means of an automated Brüel \& Kjær Environmental Noise Management System, based upon Brüel \& Kjær type 7843 management software, and Brüel \& Kjær type 3639-B-20 noise monitoring terminal $[29,30]$. Hourly, daily, monthly, and annual values of specific noise indicators were obtained from the database containing the results of 15minute measurements of equivalent noise level as a basic report format.

Table 2 Results of long-term continuous noise monitoring at measurement

\begin{tabular}{|c|c|c|c|c|}
\multicolumn{1}{c}{ points MP1 and MP2 - annual noise indicator values / dB } \\
\cline { 2 - 5 } \multicolumn{1}{c|}{} & $L_{\text {day }}$ & $L_{\text {evening }}$ & $L_{\text {night }}$ & $L_{\text {den }}$ \\
\hline MP1 & 63.4 & 63.8 & 59.5 & 67.3 \\
\hline MP2 & 68.8 & 68.2 & 64.2 & 72.1 \\
\hline
\end{tabular}

Measurement points MP1 and MP2 were chosen according to the following criteria:

- Mutually independent traffic flows;

- Heavy flow and complex structure of vehicles in the immediate surroundings; on average, over 1200 vehicles per hour during the day/evening and over 600 vehicles per hour during the night [31], which ensures a relatively continuous traffic flow; basis.

- Repeatable vehicle flow and structure on a daily

Both measurement points were exposed to broadband and time-varying noise. The chief difference in the noise content was the random daily occurrence of occasional noise events at measurement point MP1, which were caused by ambulance siren sounds.

\section{METHODOLOGY}

The reliability of applicable environmental noise monitoring programs in Serbia, reliant upon series of shortterm noise measurements, was examined by simulating the application of the programs to the results of noise monitoring obtained through continuous permanent measurement during one calendar year at measurement points MP1 and MP2.

The examination consists of the following steps:

1. Preparation of a database with the results of long-term continuous monitoring.

Data preparation for the analysis and evaluation of monitoring program reliability was made with a Python 3.7-based software specifically designed for this study, which offers the possibility of undertaking multiple iterations (repetitions of random samples and computations of required data). The software was adjusted to be compatible with different noise monitoring programs and it encompasses a variety of steps.

The input data for Leskovac and Niš are the same, containing a database with 15-minute values of equivalent noise levels by months. The database comprises special matrices for each month of the year. The matrix rows contain chronologically ordered 15-minute values of equivalent noise levels during 24 hours starting from midnight. The columns contain weekdays during a month.

The input data for Belgrade, Novi Sad, and Sombor are the same, containing a database with daily values for $L_{\text {day }}$, $L_{\text {evening }}$ and $L_{\text {night }}$ noise indicators by months. The database comprises special matrices for each month of the year. The rows contain chronologically ordered daily values for $L_{\text {day }}$, $L_{\text {evening, }}$ and $L_{\text {night }}$ noise indicators, while the columns contain weekdays during a month.

2. Calculation of $K$ annual values for $L_{\text {day }}, L_{\text {evening }}$ and $L_{\text {night }}$ noise indicators by simulating the application of a specific monitoring program through random sampling from the database created in step 1.

3. Calculation of absolute deviations obtained from the reference (measured) annual noise indicator values (Tab. 2).

4. Statistical analysis of the results obtained in step 3 by calculating the mean absolute deviations obtained from the reference annual noise indicator values $\overline{\Delta L}$ and the standard deviation of absolute deviations obtained from the reference annual noise indicator values $\sigma_{\Delta L}$ for all noise indicators.

5. Analysis and evaluation of the reliability of a specific monitoring program according to the mean value and standard deviation of absolute deviations for the basic noise indicators $L_{\mathrm{den}}$ and $L_{\text {night }}$ [21]; a more detailed analysis is possible by additionally considering the auxiliary noise indicators $L_{\text {day }}$ and $L_{\text {evening. }}$.

The mean absolute deviation obtained from the reference annual noise indicator values is the indication of a program's accuracy - a lower mean absolute deviation signifies higher program accuracy.

The precision of a program was determined based on the standard deviation of the results obtained from the random selection of values for specific quantities, repeated multiple times, which means that the standard deviation is a statistical measurement of repeatability of a result. A lower standard deviation indicates higher precision of a Program $p$. For the adopted coverage factor value $k=2$, $95 \%$ of the resulting values fall within the interval of $\pm 2 \sigma_{\Delta L}$.

6. Ranking of monitoring programs according to two groups of minimization criteria: 
Criteria group 1: $\min \left\{\overline{\Delta L_{\text {night }}}\right\}, \min \left\{\overline{\Delta L_{\text {den }}}\right\}$

Criteria group 2: $\min \left\{\sigma_{\Delta L \text { night }}\right\}, \min \left\{\sigma_{\Delta L \text { den }}\right\}$

\section{RESEARCH RESULTS AND DISCUSSION}

The results used in the analysis of reliability of selected environmental noise monitoring programs were obtained from the available database containing the results of continuous annual noise measurements at measurement points MP1 and MP2 and using the previously described methodologies.

Fig. 1 and Fig. 2 show the results of different programs' application to the reference monitoring results at measurement points MP1 and MP2, quantified by deviations calculated from the reference annual values of $L_{\text {den }}$ noise indicator.

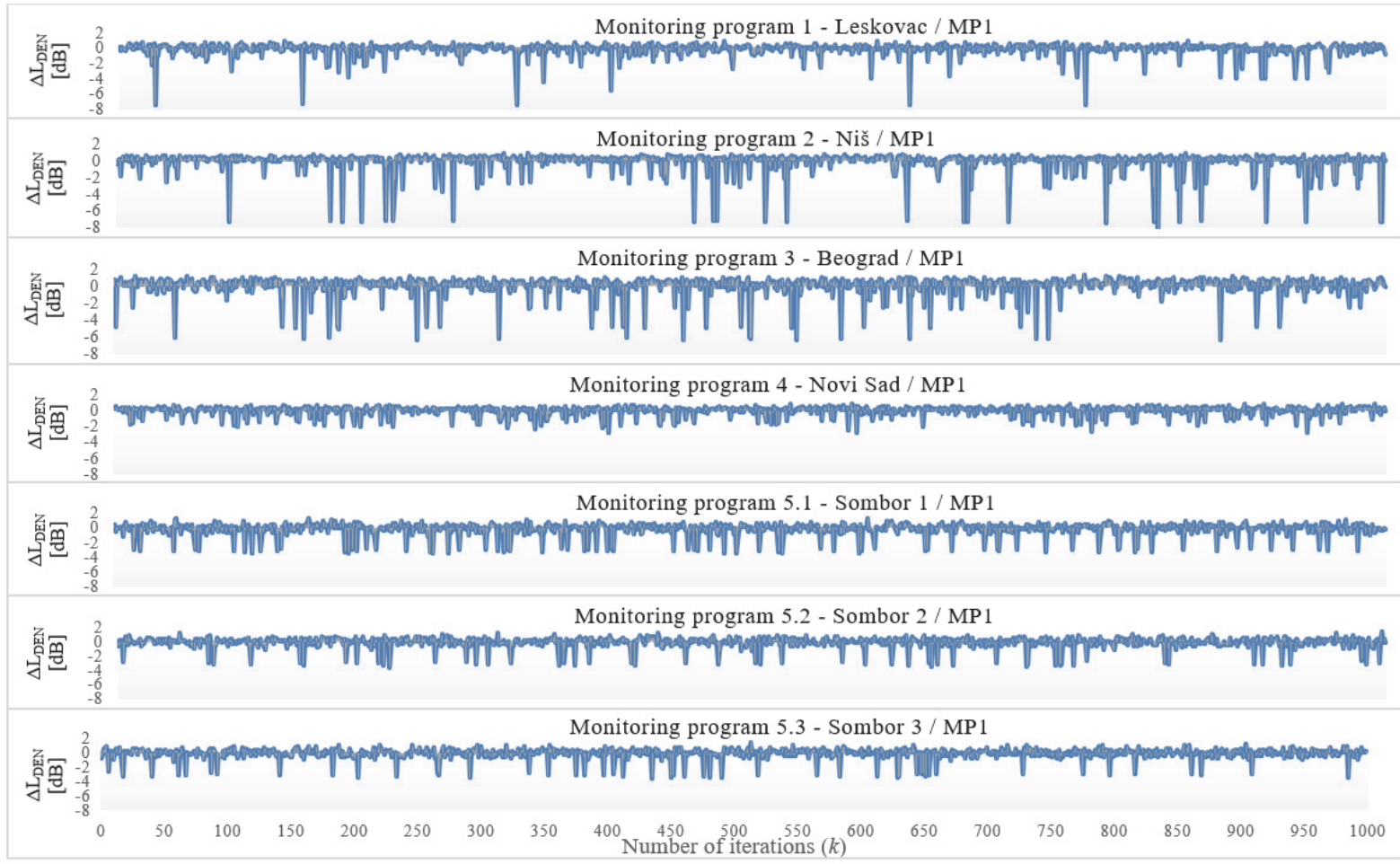

Figure 1 Deviations of annual noise indicator values based on random sample $k$ from the reference annual $L_{\text {den }}$ value (Tab. 2) simulation of the application of all programs to measurement point MP1

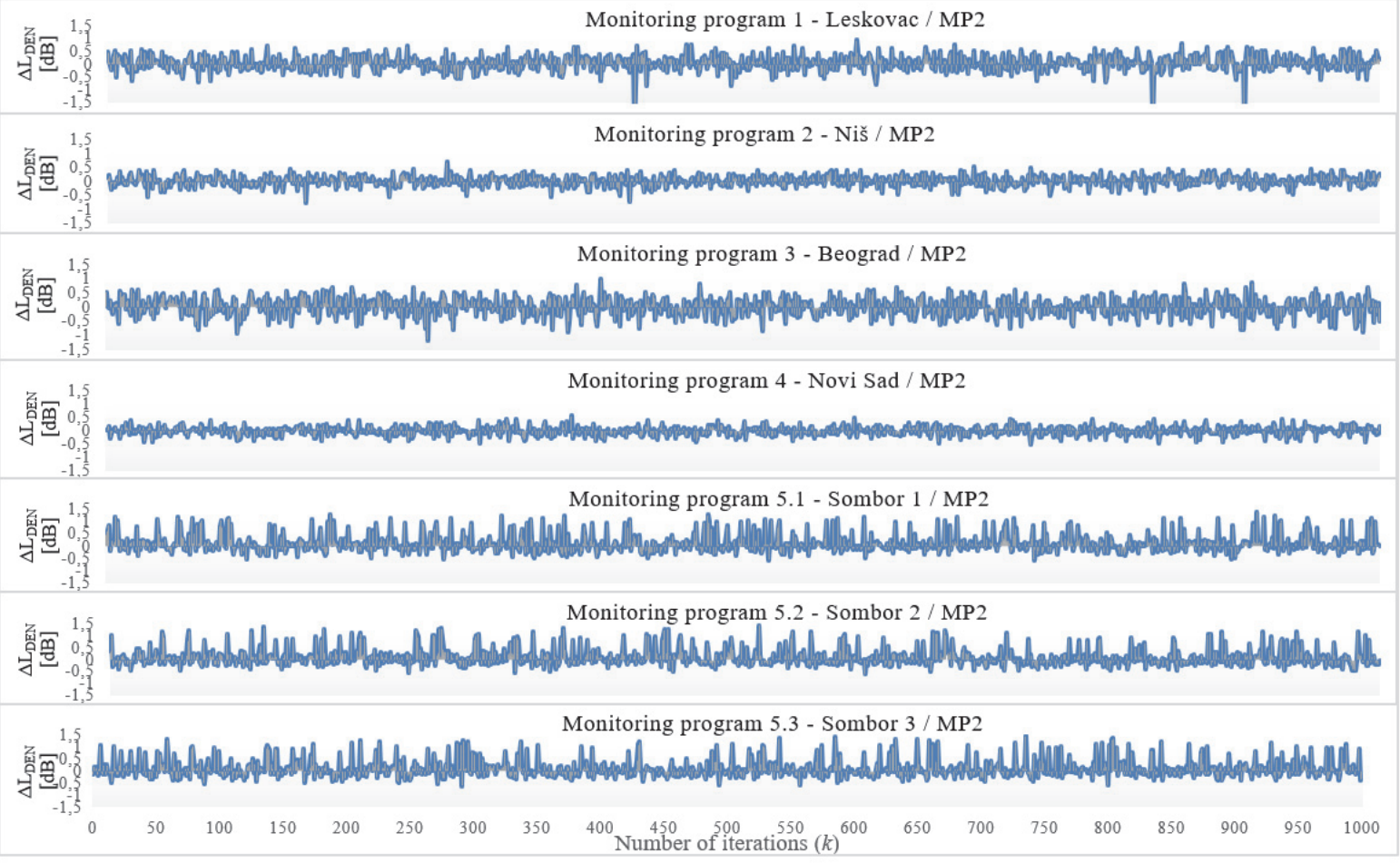

Figure 2 Deviations of annual noise indicator values based on random sample $k$ from the reference annual $L_{\text {den }}$ value (Tab. 2) simulation of the application of all programs to measurement point MP2 
Fig. 1 shows that programs 1 and 2 often exhibit particularly prominent individual $\Delta L_{\text {den }}$ values. Such values directly influence the increase of the mean value and standard deviation of absolute deviations for the $L_{\mathrm{den}}$ indicator in these programs, which negatively affects the quality of the programs in terms of result accuracy and precision. The standout values are due to occurrences of one or more noise vents during a 15-minute measurement time interval, when the equivalent noise level is high owing to a short period of averaging of the accumulated sound energy.

The reason for prominent individual $\Delta L_{\text {den }}$ values for program 3 (Fig. 1) is the small number of measurements during a year (two in total), when a randomly selected measurement day has considerably higher noise indicator values compared to the reference annual values due to certain noise events or an unusually heavy vehicle flow.

The simulation of the application of different programs to the monitoring results at two measurement points was run for the purpose of verifying the conclusions of the present study. Reliability verification of a program refers to result repeatability for the mean values and standard deviations of absolute deviations for basic noise indicators $L_{\text {den }}$ and $L_{\text {night }}$ when applied to other measurement points.

Tab. 3 shows the calculation results for all the relevant quantities used to evaluate the reliability and to verify specific programs. The results were obtained after the programs were applied to the monitoring results at measurement points MP1 and MP2.

The relationship between the mean value and the standard deviation of absolute deviations calculated from the annual values of $L_{\text {den }}$ and $L_{\text {night }}$ at measurement points MP1 and MP2 (Tab. 3 - values in bold type) indicates that program 4 (Novi Sad) has the best result repeatability after the simulation of its application to the monitoring results at measurement points MP1 and MP2 for both cases of defined criteria.

\begin{tabular}{|c|c|c|c|c|c|c|c|c|c|c|c|c|c|c|}
\hline$p$ & \multicolumn{2}{|c|}{1} & \multicolumn{2}{|c|}{2} & \multicolumn{2}{|c|}{3} & \multicolumn{2}{|c|}{4} & \multicolumn{2}{|c|}{5.1} & \multicolumn{2}{|c|}{5.2} & \multicolumn{2}{|c|}{5.3} \\
\hline Measur. point & MP1 & MP2 & MP1 & MP2 & MP1 & MP2 & MP1 & MP2 & MP1 & MP2 & MP1 & MP2 & MP1 & MP2 \\
\hline$\overline{\Delta L_{\text {day }}}$ & 0.50 & 0.30 & 0.28 & 0.22 & 0.49 & 0.31 & 0.33 & 0.24 & 0.32 & 0.29 & 0.32 & 0.29 & 0.32 & 0.30 \\
\hline$\overline{\Delta L_{\text {evening }}}$ & 0.72 & 0.28 & 0.80 & 0.26 & 1.04 & 0.34 & 0.82 & 0.19 & 1.06 & 0.33 & 0.91 & 0.32 & 0.88 & 0.33 \\
\hline$\overline{\Delta L_{\text {night }}}$ & 0.52 & 0.44 & 0.85 & 0.31 & 0.81 & 0.32 & 0.50 & 0.18 & 0.52 & 0.35 & 0.51 & 0.34 & 0.50 & 0.34 \\
\hline$\overline{\Delta L_{\mathrm{den}}}$ & 0.47 & 0.23 & 0.66 & 0.15 & 0.71 & 0.26 & 0.41 & 0.13 & 0.57 & 0.26 & 0.50 & 0.25 & 0.48 & 0.25 \\
\hline$\sigma_{\Delta L \text { day }}$ & 0.815 & 0.366 & 0.381 & 0.268 & 0.726 & 0.411 & 0.414 & 0.277 & 0.406 & 0.369 & 0.412 & 0.373 & 0.413 & 0.382 \\
\hline$\sigma_{\Delta L \text { evening }}$ & 1.500 & 0.357 & 1.654 & 0.337 & 2.075 & 0.440 & 1.360 & 0.247 & 2.128 & 0.450 & 1.811 & 0.435 & 1.751 & 0.443 \\
\hline$\sigma_{\Delta L \text { night }}$ & 0.878 & 0.565 & 1.622 & 0.387 & 1.111 & 0.394 & 0.617 & 0.229 & 0.657 & 0.505 & 0.647 & 0.482 & 0.627 & 0.501 \\
\hline$\sigma_{\Delta L \mathrm{den}}$ & 0.907 & 0.313 & 1.391 & 0.190 & 1.226 & 0.322 & 0.608 & 0.167 & 0.952 & 0.385 & 0.826 & 0.370 & 0.802 & 0.387 \\
\hline
\end{tabular}

Tab. 4 shows the ranking of programs from 1 to 7 according to the criteria of minimizing the values of reliability elements (expressions (3) and (4) above).

The ranking of result reliability for the examined programs for two cases (Tab. 4) indicates that, in terms of result reliability, program 4 (Novi Sad) is the best solution for an annual noise monitoring program at measurement points with dominant road traffic noise. Other programs yielded partially good results with relatively reliable values for only one criterion. Program 2 (Niš) may be acceptable for the monitoring of noise that does not contain any accidental and unplanned noise events.

Table 4 Program ranking according to result reliability

\begin{tabular}{|c|c|c|c|c|c|c|c|c|c|c|c|c|c|c|}
\hline & \multicolumn{14}{|c|}{ Rank } \\
\hline & \multicolumn{2}{|c|}{1} & \multicolumn{2}{|c|}{2} & \multicolumn{2}{|c|}{3} & \multicolumn{2}{|c|}{4} & \multicolumn{2}{|c|}{5} & \multicolumn{2}{|c|}{6} & \multicolumn{2}{|c|}{7} \\
\hline & MP1 & MP2 & MP1 & MP2 & MP1 & MP2 & MP1 & MP2 & MP1 & MP2 & MP1 & MP2 & MP1 & MP2 \\
\hline$\overline{\Delta L_{\text {night }}}$ & $\begin{array}{l}4 / \\
5.3\end{array}$ & 4 & $\begin{array}{l}4 / \\
5.3\end{array}$ & 2 & 5.2 & 3 & $\begin{array}{l}1 / \\
5.1\end{array}$ & $\begin{array}{c}5.2 / \\
5.3\end{array}$ & $\begin{array}{l}1 / \\
5.1\end{array}$ & $\begin{array}{c}5.2 / \\
5.3\end{array}$ & 3 & 5.1 & 2 & 1 \\
\hline$\overline{\Delta L_{\mathrm{den}}}$ & 4 & 4 & 1 & 2 & 5.3 & 1 & 5.2 & $\begin{array}{c}5.2 / \\
5.3 \\
\end{array}$ & 5.1 & $\begin{array}{c}5.2 / \\
5.3 \\
\end{array}$ & 2 & $\begin{array}{l}3 / \\
5.1 \\
\end{array}$ & 3 & $\begin{array}{l}3 / \\
5.1 \\
\end{array}$ \\
\hline$\sigma_{\Delta L \text { night }}$ & 4 & 4 & 2 & 2 & 5.3 & 3 & 5.2 & 5.2 & 5.1 & 5.3 & 3 & 5.1 & 2 & 1 \\
\hline$\sigma_{\Delta L \text { den }}$ & 4 & 4 & 5.3 & 2 & 5.2 & 1 & 1 & 3 & 5.1 & 5.2 & 3 & 5.1 & 2 & 5.3 \\
\hline$p$ & 4 & 4 & 5.3 & 2 & 5.2 & 3 & 1 & 1 & 5.1 & 5.2 & 3 & 5.3 & 2 & 5.1 \\
\hline
\end{tabular}

\section{CONCLUSIONS}

Annual environmental noise monitoring in Serbian cities is realized at a specific number of fixed measurement points using mobile instruments and according to the programs harmonized with the needs and capacities of local self-governments. Depending on the requirements, reports on monitoring results are created periodically - both monthly and annually, only annually, or any other period specified by the monitoring program. The elements of a noise monitoring program, such as measurement point location, measurement time interval, and measurement schedule during a year, are crucial for the reliability of noise measurement results and thus of the program itself.

The results obtained in this study indicated that, with higher or lower degrees of reliability, different programs can be used to monitor noise at measurement points next to major urban roads with heavy and relatively constant vehicle flow throughout the day. If it is not possible or even required to conduct continuous annual noise monitoring, 
the noise at locations with the same daily noise profile and the occasional occurrence of unplanned short-term noise events can also be monitored with sufficient reliability using a series of short-term measurements on a monthly schedule and a measurement time interval encompassing 24 hours.

\section{Acknowledgements}

This research is conducted under the auspices of Ministry of Education, Science and Technological Development of the Republic of Serbia.

\section{REFERENCES}

[1] World Health Organization. (2018). Environmental noise guidelines for the European region. Retrieved from https://www.euro.who.int/_data/assets/pdf_file/0008/3839 21/noise-guidelines-eng.pdf?ua $=1$

[2] Mihajlov, D. I., Prascevic, M. R., \& Gajicki, A. (2015). Assessment of harmful health impact of environmental noise. Facta Universitatis, Series: Working and Living Environmental Protection, 12(1), 9-16.

[3] Papadimitriou, E. A., Papageorgiou, G. P., Alamanis, N., \& Diakosavva, T. N. (2020). Road Noise Levels in Urban Environment Compared to Specification Limits. The Case of the City of Larissa, Greece. Periodica Polytechnica Civil Engineering, 64(4), 964-974. https://doi.org/10.3311/PPci.14868

[4] Hellmuth, T., Classen, T., Kim, R., \& Kephalopoulos, S. (2012). Methodological guidance for estimating the burden of disease from environmental noise. WHO Regional Office for Europe. Retrieved from

https://www.euro.who.int/_data/assets/pdf_file/0003/1778 16/Methodological-guidance-for-estimating-the-burden-ofdisease-from-environmental-noise.pdf

[5] de Roo, F. (2013, September). New EU and UN/ECE vehicle noise emissions limits and associated measurement methods. INTER-NOISE and NOISE-CON Congress and Conference Proceedings, 247(1), 6415-6430.

[6] Bogdanović, G. (2016). The problem communal noise in city of Vranje. Journal of Process Management. New Technologies, 4(4). https://doi:10.5937/jouproman4-12108

[7] Tomić, J., Georgijev, Z., Pljakić, M., \& Radičević, B. (2019). Systematic Noise Monitoring in the Territory of Autonomous Province of Vojvodina. ENVIRONMENT AND PEOPLE (CCEDEP 2019) Novi Sad, Sremska Kamenica, Serbia, 24th October 2019., 221.

[8] Pljakić, M., Radičević, B., Tomić, J., \& Petrović, Z. (2012, October). Analysis of systematic measurements of noise in cities. Proceedings of 23rd Conference with International Conference "Noise and Vibration, 59-62.

[9] Prascevic, M. R., Mihajlov, D. I., \& Cvetkovic, D. S. (2014). Measurement and evaluation of the environmental noise levels in the urban areas of the city of Nis (Serbia). Environmental monitoring and assessment, 186(2), 11571165. https://doi.org/10.1007/s10661-013-3446-2

[10] Rubežić, M. (2017). Legal framework of protection from community noise in the Republic of Serbia and its compliance with Directive 49/2002/EC. Glasnik Advokatske komore Vojvodine, 89(9-12), 419-442. https://doi.org/10.5937/gakv1712419R

[11] Giovanni, Z., Fabio, A., Diego, S., Walter, Z., \& Maura, S. Traffic noise monitoring in the city of milan: construction of a representative statistical collection of acoustic trends.

[12] Ruiz-Padillo, A., Ruiz, D. P., Torija, A. J., \& Ramos-Ridao, Á. (2016). Selection of suitable alternatives to reduce the environmental impact of road traffic noise using a fuzzy multi-criteria decision model. Environmental Impact Assessment Review, 61, 8-18. https://doi.org/10.1016/j.eiar.2016.06.003

[13] Zambon, G., Roman, H. E., Smiraglia, M., \& Benocci, R. (2018). Monitoring and prediction of traffic noise in large urban areas. Applied Sciences, 8(2), 251. https://doi.org/10.3390/app8020251

[14] Lakušić, S., \& Ahac, M. (2012). Rail traffic noise and vibration mitigation measures in urban areas. Technical Gazette, 19(2), 427-435.

[15] Tomić, J., Bogojević, N., Pljakić, M., \& Šumarac-Pavlović, D. (2016). Assessment of traffic noise levels in urban areas using different soft computing techniques. The Journal of the Acoustical Society of America, 140(4), EL340-EL345. https://doi.org/10.1121/1.4964786

[16] Vasilyev, A. V. (2017). New methods and approaches to acoustic monitoring and noise mapping of urban territories and experience of it approbation in conditions of Samara region of Russia. Procedia Engineering, 176, 669-674. https://doi.org/10.1016/j.proeng.2017.02.311

[17] Prascevic, M., Cvetković, D., Mihajlov, D., Petrović, Z., \& Radičević, B. (2013). Verification of NAISS model for road traffic noise prediction in urban areas. Elektronika ir elektrotechnika, 19(6), 91-94.

[18] Stančerić, I., Dragčević, V., \& Ahac, S. (2010). Toward environmental noise estimation according to the road surface characteristics and traffic volume. Technical Gazette, 17(2), 191-197.

[19] Aumond, P., Can, A., Mallet, V., Gauvreau, B., \& Guillaume, G. (2021). Global sensitivity analysis for road traffic noise modelling. Applied acoustics, 176, 107899. https://doi.org/10.1016/j.apacoust.2020.107899

[20] Alam, P., Ahmad, K., Afsar, S. S., \& Akhtar, N. (2020). Noise Monitoring, Mapping, and Modelling Studies - A Review. Journal of Ecological Engineering, 21(4). https://doi.org/10.12911/22998993/119804

[21] Directive 2002/49/EC. Assessment and Management of Environmental Noise. European Parliament, Council of the European Union. Retrieved from https://eurlex.europa.eu/legalcontent/EN/TXT/PDF/?uri=CELEX:320 02L0049 \& from $=\mathrm{EN}$

[22] International Organization for Standardization. (2017). Acoustics - Description, measurement and assessment of environmental noise - Part 2: Determination of sound pressure levels (ISO Standard No. 1996-2:2017).

[23] Mihajlov, D., Praščević, M., \& Cvetković, D. (2012). An analysis of the environmental noise levels on the territory of the city of niš.

[24] Law on environmental noise protection of Republic of Serbia. Official Gazette of Republic of Serbia, 36/2009, $88 / 2010$.

[25] Jagniatinskis, A., Fiks, B., Zaporozhets, O., \& Mickaitis, M. (2017). Annual assessment of noise generated by road traffic using measurements. Procedia Engineering, 187, 614-619. https://doi.org/10.1016/.jproeng.2017.04.421

[26] See http://certificacioacustica.cat/wp-content/uploads/ D5 IMA32TR-040510-SP08.pdf

[27] Mihajlov, D. I. \& Prascevic, M. R. (2015). Permanent and semi-permanent road traffic noise monitoring in the city of Nis (Serbia). Journal of low frequency noise, vibration and active control, 34(3), 251-268. https://doi.org/10.1260/0263-0923.34.3.251

[28] Mihajlov, D., Praščević, M., \& Herisanu, N. (2018). Selection of measurement strategy for the assessment of long-term environmental noise indicators using multicriteria optimization. Acoustics and Vibration of Mechanical Structures - AVMS-2017, 77-82. https://doi.org/10.1007/978-3-319-69823-6_9

[29] Technical documentation - Noise Monitoring terminal Types 3639-A, 3639-B and 3639-C with Hand-held Analyzer Type 
2250-N or Hand-held Analyzer Type 2250-N-D00, version 4.1.1, Bruel \& Kjaer, BE 1818-17, 2013.

[30] Technical documentation - Environmental Noise Management System Software Type 7843, version 2.8.1, Bruel \& Kjaer, BE 1767-15, 2010.

[31] COWI d.o.o. Belgrade (2010). Study of checking the capacity of the traffic network of the city of Niš for the development of the General Plan of City of Niš, Book 1: Research of the characteristics of traffic flows.

\section{Contact information:}

Darko MIHAJLOV, PhD, ass. prof. (Corresponding author)

Fakultet zaštite na radu u Nišu

Čarnojevića 10a, 18000 Niš, Srbija

E-mail: darko.mihajlov@znrfak.ni.ac.rs

Momir PRAŠČEVIĆ, PhD, full prof.

Fakultet zaštite na radu u Nišu,

Čarnojevića 10a, 18000 Niš, Srbija

E-mail: momir.prescevic@znrfak.ni.ac.rs

Marko LIČANIN, MSc, assistant

Fakultet zaštite na radu u Nišu,

Čarnojevića 10a, 18000 Niš, Srbija

E-mail: marko.licanin@znrfak.ni.ac.rs

Miomir RAOS, PhD, full prof.

Fakultet zaštite na radu u Nišu,

Čarnojevića 10a, 18000 Niš, Srbija

E-mail: miomir.raos@znrfak.ni.ac.rs 